\title{
Overfat Adults and Children in Developed Countries: The Public Health Importance of Identifying Excess Body Fat
}

\author{
Philip B. Maffetone ${ }^{1 *}$, Ivan Rivera-Dominguez ${ }^{2}$ and Paul B. Laursen ${ }^{3}$ \\ ${ }^{1}$ Independent Researcher, Oracle, AZ, United States, ${ }^{2}$ Research Assistant, San Diego, CA, United States, ${ }^{3}$ Sports \\ Performance Research Institute New Zealand (SPRINZ), Auckland University of Technology, Auckland, New Zealand
}

OPEN ACCESS

Edited by:

Beverly Sara Muhlhausler, University of Adelaide, Australia

Reviewed by: Nina Eikelis,

Swinburne University of Technology, Australia Claire Joanne Stocker, University of Buckingham, United Kingdom

${ }^{*}$ Correspondence: Philip B. Maffetone philmaffetone@gmail.com

Specialty section: This article was submitted to Obesity, a section of the journal Frontiers in Public Health

Received: 26 May 2017 Accepted: 12 July 2017

Published: 24 July 2017

Citation:

Maffetone PB, Rivera-Dominguez I and Laursen PB (2017) Overfat Adults and Children in Developed

Countries: The Public Health Importance of Identifying Excess

Body Fat.

Front. Public Health 5:190. doi: 10.3389/fpubh.2017.00190
The global overfat pandemic is a serious public health crisis that places a substantial burden on economic resources in developed countries. The term overfat refers to the presence of excess body fat that can impair health, even for normal weight non-obese individuals. Excess body fat is associated with cardiometabolic dysfunction, a clinical situation that can progressively worsen, potentially leading to various common disease risk factors, chronic diseases, increased morbidity and mortality, and reduced quality of life. The prevalence of overfat populations in 30 of the world's most developed countries is substantially higher than recent global estimations, with the largest growth due to a relatively recent increased number of people with excess abdominal fat. Abdominal overfat is the most unhealthful form of this condition, so it is concerning that average waist circumference measures, generally indicative of abdominal overfat, have increased. Despite a leveling off appearance of being overweight and/or obese in some developed countries, the overfat pandemic continues to grow.

Keywords: obesity, abdominal obesity, overweight, chronic disease, inflammation, insulin resistance

\section{KEY FINDINGS}

On average, the prevalence of overfat adults and children in developed countries is extremely high, and substantially greater than that of overweight and obese individuals.

In the US, New Zealand, Greece, and Iceland, prevalence of the overfat condition is at an alarmingly high rate of over $90 \%$ in adult males and up to $50 \%$ in children.

Despite a leveling off appearance of the overweight and/or obese condition in some developed countries, the overfat pandemic continues to grow.

In tandem with an increased average waist circumference, a recent rise in the incidence of abdominal adiposity, the unhealthiest form of excess body fat, has been observed in both adults and children.

\section{INTRODUCTION}

It was recently estimated that between 62 and $76 \%$ of the world's population have reached body fat levels that can impair health (1). This condition, which can now be labeled a pandemic, was described by the catch-all term overfat (Table 1). It is well-recognized that the overweight and obese conditions represent a continuing threat to world health, replacing more traditional problems of undernutrition 
TABLE 1 | Commonly used abbreviations and definitions.

\begin{tabular}{|c|c|c|}
\hline Term & Abbreviation & Definition \\
\hline Overfat & - & $\begin{array}{l}\text { Excess body fat that can impair } \\
\text { health }\end{array}$ \\
\hline Body fat percentage & BFP & Total\% body fat vs. lean mass \\
\hline Body mass index & $\mathrm{BMl}$ & $\begin{array}{l}\text { Weight in kilograms divided by } \\
\text { height in square meters }\end{array}$ \\
\hline $\begin{array}{l}\text { Metabolically obese } \\
\text { normal weight }\end{array}$ & MONW & $\begin{array}{l}\text { Normal-weight overfat with } \\
\text { cardiometabolic dysfunction }\end{array}$ \\
\hline Normal weight obese & NWO & $\begin{array}{l}\text { Normal weight overfat with } \\
\text { cardiometabolic dysfunction }\end{array}$ \\
\hline $\begin{array}{l}\text { Metabolically healthy } \\
\text { obese }\end{array}$ & $\mathrm{MHO}$ & $\begin{array}{l}\text { Overfat with little/no measurable } \\
\text { health risk }\end{array}$ \\
\hline Waist circumference & WC & Measure of waist in centimeters \\
\hline Waist-to-height ratio & WHtR & $\begin{array}{l}\text { Ratio of waist-to-height in } \\
\text { centimeters }\end{array}$ \\
\hline
\end{tabular}

and infectious diseases. Indeed, being overfat shares direct links to insulin resistance and chronic inflammation, and to hypertension, dyslipidemia, coronary heart disease, stroke, cancer, Type 2 diabetes, gallbladder disease, osteoarthritis and gout, pulmonary diseases, sleep apnea, and others (2). Global rates of these conditions in adults and children (including adolescents) have risen significantly over the past $\sim 40$ years, paralleling significant increases in the numbers classified as being overweight and obese, and considerably affecting people of all ages and incomes in both developed and developing countries (3).

While the prevalence of being overweight and obese is well known (4), many normal-weight and non-obese individuals exhibit excess levels of body fat that can adversely affect their health (5-7). Indeed, reliance of body mass index (BMI) for determination of being overweight and obese may misclassify up to $50 \%$ or more of patients with excess body fat who may have increased health risks $(8,9)$. The notion of a metabolically obese normal weight (MONW) individual is based on the finding that obesity-associated disorders such as high circulating insulin levels in people with cardiovascular disease or Type 2 diabetes can occur in those with normal BMI (10-14). Many at-risk individuals have been identified in a BMI range of 23-25 or lower (11). Overfat individuals who are not overweight and obese include MONW individuals $(10,15,16)$, those with sarcopenic obesity (17), and many who have increased abdominal fat stores. Abdominal and visceral fat accumulation, regardless of weight status, has been found to increase risk of cardiovascular and metabolic (cardiometabolic) disease to the greatest degree (10, 18-20).

In addition, the similar concept of normal weight obesity (NWO) expands on the notion of MONW by describing the association between normal weight and high body fat percentage (BFP) with cardiometabolic abnormalities (21). Oliveros et al. (22) refer to MONW individuals as a likely subset of NWO people. Thus, we include both categories in our estimations of overfat populations herein.

Body mass index is calculated as body weight (in kilograms) divided by height (in meters) squared, with the World Health Organization (WHO) defining overweight as having a $\mathrm{BMI} \geq 25-29.9$ and obesity as having a BMI $\geq 30 \mathrm{~kg} / \mathrm{m}^{2}(2,4)$.
While it is well-known that central to the pathophysiology of obesity is an excess amount of adiposity, clinicians and researchers usually rely on BMI (which does not directly estimate body fat) to define the presence of adiposity or obesity-a practice strengthened by the discovery of an association between BMI and increased mortality (23).

However, large multiethnic samples from the US general population have demonstrated that BMI has limited diagnostic performance in correctly identifying individuals with excess body fat, particularly in those with BMI $<30 \mathrm{~kg} / \mathrm{m}^{2}$, with BMI missing more than half of people with BFP-defined obesity $(8,9)$. For example, Hung has shown that up to $70 \%$ of young women with high BFP would be missed by BMI category alone (24). The main limitation of $\mathrm{BMI}$ is that it cannot differentiate fat mass from lean mass, or central from peripheral fat $(5,22)$. Furthermore, the relationship between BMI and BFP varies considerably among different ethnic groups, further lowering the utility of BMI as a predictive measure of adiposity and health risk for many groups of people $(25,26)$.

Regardless of body weight or BMI, excess BFP in adults is associated with a wide range of cardiometabolic dysregulation, as indicated by various risk factors associated with downstream disease and mortality (5-7). In particular, excess BFP is associated with elevated fasting triglycerides and glucose, low HDL and high LDL cholesterol, increased blood pressure, a higher odds ratio of developing the metabolic syndrome, along with Type 2 diabetes, cardiovascular disease, and other chronic illness, with increased mortality as a consequence. The earliest dysregulation is often observed now in children $(10,27)$.

Perhaps the earliest onset of cardiometabolic dysregulation begins as a vicious cycle of excess body fat, insulin resistance, and chronic, low-grade systemic inflammation $(28,29)$. Excess adiposity is a source of inflammatory molecules that can disrupt glucose homeostasis and contribute to the pathogenesis of insulin resistance $(30,31)$. In turn, insulin resistance further exacerbates adiposity by influencing glucose disposal and fat storage. As such, the overfat condition potentially contributes to two adverse metabolic conditions (chronic inflammation and insulin resistance), which then contribute to further adiposity. This is in effect a vicious cycle wherein the appearance of adiposity and its initial consequences feed back into themselves, accelerating and entrenching the dysregulation (See Figure 1).

An updated definition of obesity based on adiposity, not on body weight, is urgently needed (22). As we have argued, the term overfat fills this void. As such, the term may be better suited to help public health efforts in reducing cardiometabolic risk factors and preventing disease, improving quality of life, and mitigating the economic burden of this global problem.

\section{Calculation of Fat Mass}

The methods used to quantify BFP include bioelectrical impedance, hydrostatic plethysmography, isotope dilution techniques, dual $\mathrm{x}$-ray absorptiometry (DXA), skinfold method, body impedance measures, and others, with DXA one of the most accurate and precise methods available to measure total body fat and lean soft tissue mass directly (32). Epidemiologic studies have also demonstrated that central fat distribution assessed through waist circumference 


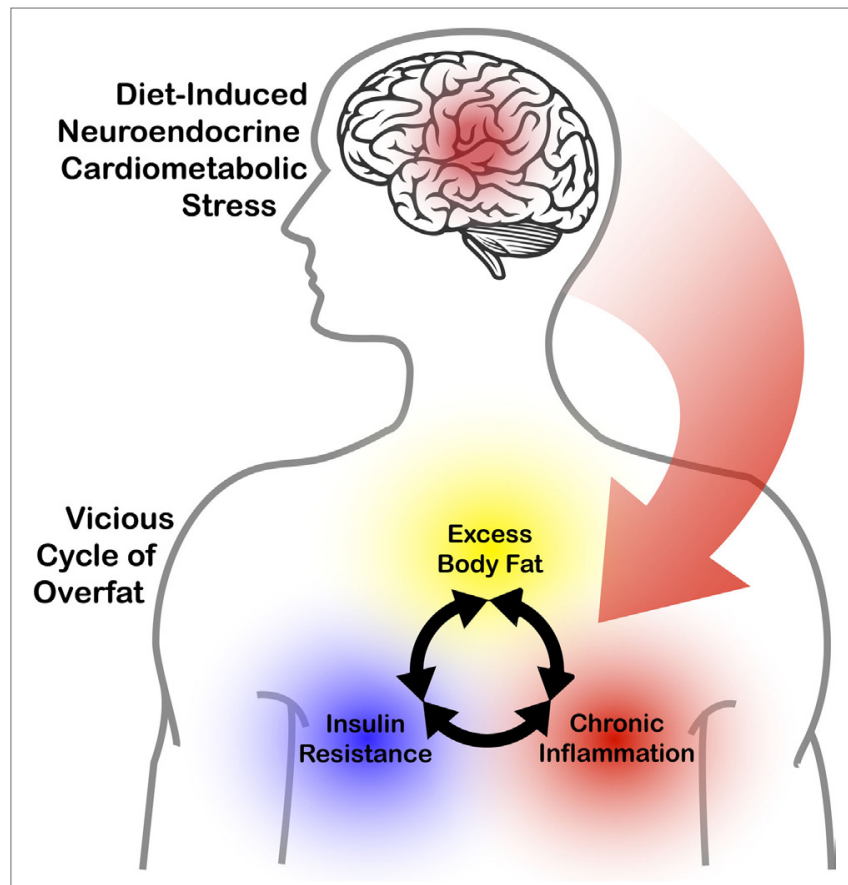

FIGURE 1 | The impact of diet-induced neuroendocrine cardiometabolic stress on the interrelationship between excess body fat, chronic inflammation, and insulin resistance.

(WC), waist-to-hip ratio, and waist-to-height ratio (WHtR) measures can be very useful in assessing adiposity-related risk (22); although, like BMI, these measurements cannot estimate BFP.

While there is still no consensus on normal BFP cutoffs, Gallagher et al. (33) suggest they should vary with age such as $20-39$ years, $>19$ and $>32 \% ; 40-59$ years, $>21$ and $33 \%$; and $60-79$ years, $>24$ and $35 \%$ for men and women, respectively (33). Body fat distribution, genetics, and fitness also can contribute to the development of health risk factors.

Recent large-scale epidemiological analyses, such as the 2013 Global Burden of Disease (GBD) study reported in Ng et al. (4), have attempted to provide a picture of obesity-related health risk on a worldwide scale, defining the prevalence of overweight and obese conditions using common BMI conventions for adults (overweight as $\geq 25$ to $<30 \mathrm{~kg} / \mathrm{m}^{2}$ and obesity as $\geq 30 \mathrm{~kg} / \mathrm{m}^{2}$ ). Childhood obesity is often based on the International Obesity Task Force definition, which established definitions for global classification of children as overweight and obese (34).

The implications of relying on BMI as a principal measure of obesity are not limited to the context of clinical diagnosis of individuals. Indeed, doctors often have access to other tools that allow them to correct for the drawbacks of BMI. The larger problem is that most large-scale epidemiological studies that use BMI have no way of correcting for the metric's disadvantages. As a result, these studies may have substantially underreported the population of individuals who are at risk of obesity-related cardiometabolic disease. Effectively, overreliance on BMI may have serious implications on our ability to size the problem, and therefore on our ability to properly address its consequences.
A central purpose of this paper is to take recent theory and data on normal weight non-obese populations at cardiometabolic risk due to excess body fat, combine them with those who are overweight and obese, and provide preliminary estimates of overfat people in 30 of the most developed countries according to the Human Development Index (HDI), as described in the Human Development Report for 2014, authored by the United Nations Development Program (35). Our expectation was that developed countries would show a higher proportion of overfat individuals, in part due to lower levels of underfat, with developing nations outnumbering developed ones by more than 6:1 (36).

\section{OVERFAT AS A RISK FACTOR}

Overfat individuals may be at increased risk for developing a wide range of health problems, including cardiometabolic abnormalities, downstream diseases, and increased morbidity and mortality $(5,37)$. Overweight and obesity alone represents the fifth leading risk for global deaths (38) and is projected to become the most common modifiable factor among preventable causes of global death (39). Estimating the extensive prevalence of overfat can add to our public health knowledge in addressing the pandemic, including preventing the earliest forms of chronic illness.

\section{Clustering of Subclinical Risk Factors}

The potential for a single risk factor to have clinical value should not be underestimated and could very well be the earliest sign of future disease (40). The overfat condition can be understood as a subclinical risk factor, which can precede the more significant cardiometabolic dysregulations noted above. Increased WC alone, such as in normal-weight individuals, is associated with the metabolic syndrome, as are other subclinical conditions such as prediabetes (41) and prehypertension (42).

The National Health and Nutrition Examination Survey (NHANES) III attempted to establish the relationship between health and nutrition in the United States population. In this study, within the group of normal-weight adults with higher BFP, the prevalence of metabolic syndrome and its individual components was shown to increase linearly with increases in BFP (5). In a study of Brazilian adults (20-23 years), higher BFP in normal weight was also associated with metabolic syndrome and insulin resistance (43).

The clustering of risk factors, such as those observed in metabolic syndrome, MONW, and NWO, suggests that more than one primary abnormality typically exists in certain individuals. For example, a predisposition to glucose intolerance, associated with insulin resistance, may be a common factor in the case of those who are overfat (44). A significant number of other cardiometabolic risk factors were also shown in up to $30 \%$ of normal weight, non-obese male individuals who demonstrated impaired fasting glucose (45). Adiposity and weight gain were key determinants of the degree of clustering of cardiometabolic risk factors in Framingham study participants, with increased WC being a primary factor (40). Within this larger clustering occurs the chronic, smaller category of metabolic syndrome. Wilson and Meigs (40) state that, "Excess adiposity, especially abdominal adiposity, and insulin resistance are probably key ingredients that lead to the 
development of the risk factor abnormalities that then translate into the clinical outcomes."

Unfortunately, most of the studies demonstrating clustering of common conditions do not include well-described subclinical disorders that can pre-date disease states, such as prehypertension and prediabetes. Future studies should address relationships between these very early risk factors with that of glucose intolerance and insulin resistance, and its impact on cardiometabolic health $(46,47)$. This might also include evaluating overfat children, whose conditions can play a key role in the advent of downstream diseases typically exhibited in adulthood. Unfortunately, adiposity in children is likely to feed the overfat pandemic because research shows that obese children are at increased risk for becoming obese adults with chronic disease (48-53).

\section{Clustering of Clinical Risk Factors}

Since the early observations of Ruderman et al. in 1981, the list of associated disorders clustered in normal-weight overfat populations has grown (11). Rather than thinking of these disorders as separate, individual clinical problems, it might be best to consider the relationships between overfat, its various risks, and its associated downstream diseases as a spectrum or progression where the vicious cycle of overfat, insulin resistance and chronic inflammation lies at one end, (constituting the population with early measurable abnormality), while the presence of chronic conditions resides at the other end (see Figure 2).

Prevalence of the conditions listed in Figure 2 is also increased in individuals with a history of low birth weight, as well as in normal-weight $(<25 \mathrm{BMI})$ offspring and other first-degree relatives of patients with these conditions (10). A preliminary evaluation of the offspring (mean age 54 years) of the original Framingham study cohort found that $44 \%$ of the population had one or more abnormal findings associated with insulin resistance (54). Other associated disorders include (1) neuroinflammation, which can affect the function of the hippocampus, cortex, brainstem, or amygdala, with clinical conditions such as depression and impaired cognitive function (55), as well as (2) reduced quality of life, which includes a twofold risk of physical activity difficulties such as walking and climbing stairs, increased pain, and hindrance to daily activities (56).

Another cardiometabolic risk is cancer-related clustering of prediabetes, diabetes, metabolic syndrome, and chronic inflammation (57). The cancer-obesity connection in the past was limited to a small number of cancers. However, Lauby-Secretan et al. (58) recently emphasized that the absence of excess body fat lowers the risk of most cancers and discussed the possibility that the association between higher body fat and cancer risk is causal. In addition, survival rates among persons with chronic diseases such as cancer may decrease, as increased body fat is associated with worse treatment outcomes (59).

To summarize, whether an individual presently meets the criteria for NWO but not MONW (or for MONW but not for metabolic syndrome) is inconsequential to whether they are overfat, and therefore at increased risk of downstream cardiometabolic impairment.

\section{Is Obesity Leveling? Overfat Is Not}

Based on BMI evaluations, there appears to be a leveling off of the trend in rising obesity rates in some developed nations $(60,61)$

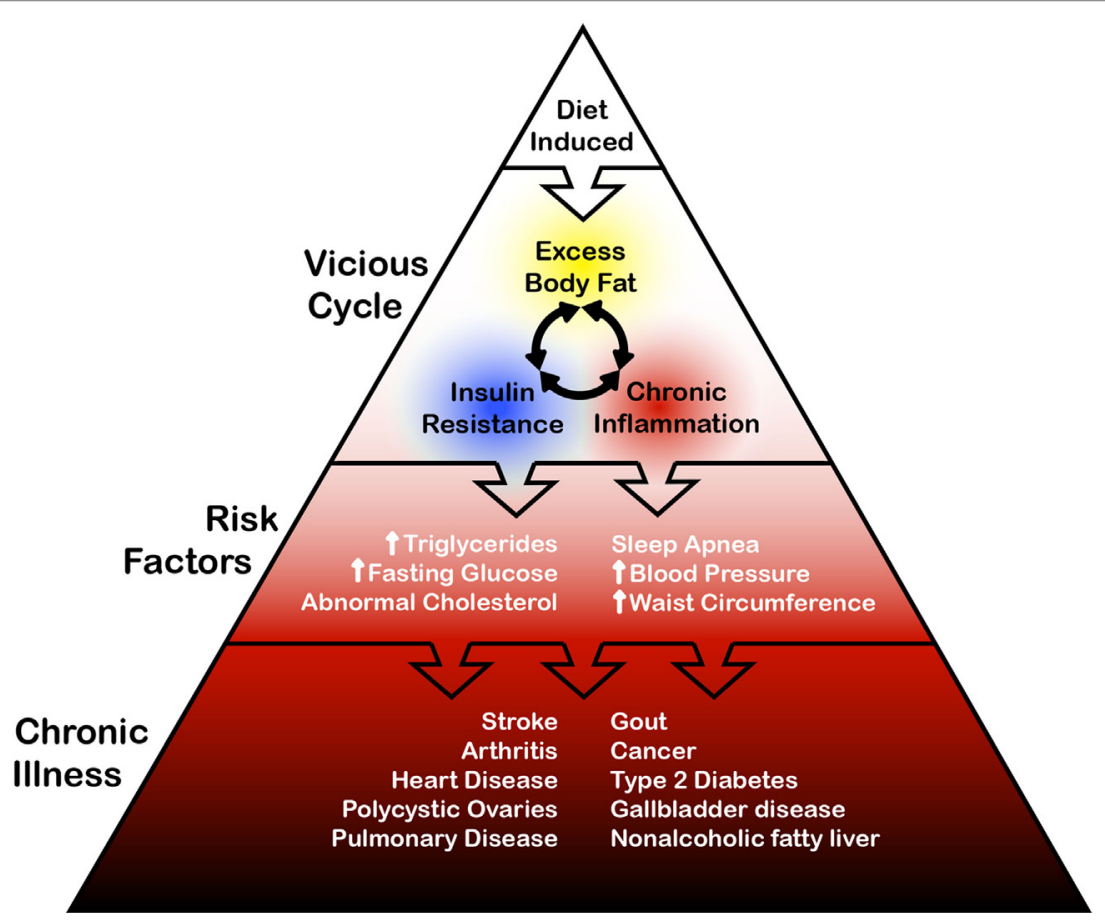

FIGURE 2 | General schematic of relationships between diet, overfat, some risk factors, and chronic illness. 
However, the incidence of central adiposity - the excess accumulation of visceral fat in the abdominal region, sometimes called abdominal obesity (62) - is increasing (61). This form of overfat is concerning because the potential health risks of central adiposity are more pronounced than those for increased subcutaneous fat in other regions of the body (63). The continued increase in abdominal obesity includes those who are normal weight and non-obese, with US population averages of 54.2\% (51.3-57\%), and an increased prevalence in women (up to 68.3\%) (61).

It may be too early to make the claim on a leveling of obesity rates for various reasons. Previous stable phases of the obesity epidemic have been followed by further increases (64). There are also increased rates of abdominal obesity as indicated by increases in WC $(61,65)$. While obesity has recently plateaued at $35 \%$ for US men, it continues to increase to $40 \%$ for women, with a similar trend in the 60 years and older group (66), with morbid obesity rates continuing to rise in developed countries $(67,68)$. One billion adults are projected to have obesity by 2025, far more than the current levels (69). In addition, younger generations are becoming obese at an earlier age and are staying obese for a longer duration than older generations (70).

The notion that obesity in some countries has slowed or leveled may constitute an inconsistent public health message that erroneously implies we are solving a serious problem while the overfat pandemic continues to grow. Despite the trends in overfat, weight counseling and clinical diagnosis of overweight and obesity in US primary care significantly declined between 1995-1996 and 2007-2008 (71, 72). In addition, fewer overweight and obese adults report trying to lose weight between 1988-1994 and 2009-2014, with percentages declining from 56 to $49 \%$, respectively (73).

\section{Metabolically Healthy Obese (MHO)}

Researchers have described $\mathrm{MHO}$ individuals, a prevalence estimated at 7.27\% (74), who, despite having BMI > 30, appear relatively insulin sensitive and lack some or most of the metabolic abnormalities typical of obese individuals (75-78). Even though conditions such as metabolic syndrome may not be prevalent in $\mathrm{MHO}$ individuals, the presence of fewer (or other) cardiometabolic risk factors typically associated with obesity can still exist. Within these, being overfat is the critical factor that confers risk for Type 2 diabetes and CVD associated with adiposity (37). In a large, community-based sample of men and women across a broad age spectrum, Meigs et al. (37) stated that MHO subjects were younger than obese subjects with metabolic syndrome, but as they age, they may transition from obese and apparently healthy to obese with risk factor clustering. This implies that $\mathrm{MHO}$ individuals may be in the process of becoming metabolically unhealthy. Wang et al. (74) showed that the prevalence of MHO was lower for adults $>40$ years than the general population, and that these individuals were at increased risk for all-cause mortality and/ or cardiovascular events over the long-term ( $\geq 10$ years). Other studies have noted that these seemingly healthy obese subjects may have subclinical disease, concluding that longer follow-ups or more careful evaluation may be required before referring to them as healthy $(79,80)$. As such, we consider so-called MHO individuals to also be overfat (22).

\section{Economics of Overfat}

The economic fallout from the overfat pandemic has raised a serious global challenge. In 2011, the WHO estimated that the economic burden of preventable, non-communicable disease (in particular cardiovascular disease, cancer, and diabetes) is expected to create a cumulative output loss of US $\$ 47$ trillion over the next two decades (81). In 2010, this represented $75 \%$ of global GDP (US\$ 63 trillion)-enough capital to lift the 2.5 billion people currently below the poverty line, out of poverty for more than half a century. While it is difficult to determine the absolute burden of the overfat pandemic, it is clearly a strong causal factor in the development of a significant portion of chronic disease and reduced quality of life.

\section{WHO IS OVERFAT}

It is important to recognize high-risk populations for better adiposity-based risk stratification, along with a need for an updated definition of obesity based on adiposity, not on body weight (22). We previously estimated the global prevalence of the overfat population using several subpopulations that included those who are overweight, obese, MONW individuals, those with sarcopenic obesity and others (1). Additionally, the overfat pandemic has not spared physically active people, including professional athletes in various sports $(82,83)$ and active US military personnel $(84,85)$.

Unique to developed countries are the recently increased numbers of older persons more likely to develop sarcopenic obesity, and the increase in abdominal obesity that outpaces increases in BMI. We introduce two new additional terms to more accurately describe excess fat accumulation in those who are sarcopenic and those with increased abdominal adiposity. Specifically, because the term "obesity" has historically been explicitly based on BMI, its use to describe these two body compositions is arguably incorrect and may even be confusing to the public and media. We therefore aim to better define and draw attention to two growing components of the overfat pandemic, sarcopenic overfat, and abdominal overfat.

\section{Sarcopenic Overfat}

Sarcopenia is defined as the progressive loss of type II fast-twitch muscle fibers and strength with aging and is an important public health problem with a prevalence as high as $50 \%$ in those $>80$ years (86). Muscle atrophy can coexist with an accumulation of fat within existing muscle, and the combination of higher body fat and sarcopenia has been termed sarcopenic obesity $(87,88)$, which we refer to henceforth in this paper as sarcopenic overfat. This condition is associated with low-grade chronic inflammation, insulin resistance, elevated C-reactive protein, and excessive oxidative stress (17). Sarcopenia increases the risk of disability and poor quality of life, and death, and may have an important association with chronic illness and aging. In the elderly, who naturally exhibit the highest rates of mortality in survival studies, the diagnostic performance of BMI is at its worst, likely to be highly under-estimating the extent of overfat people with sarcopenic overfat (8). 


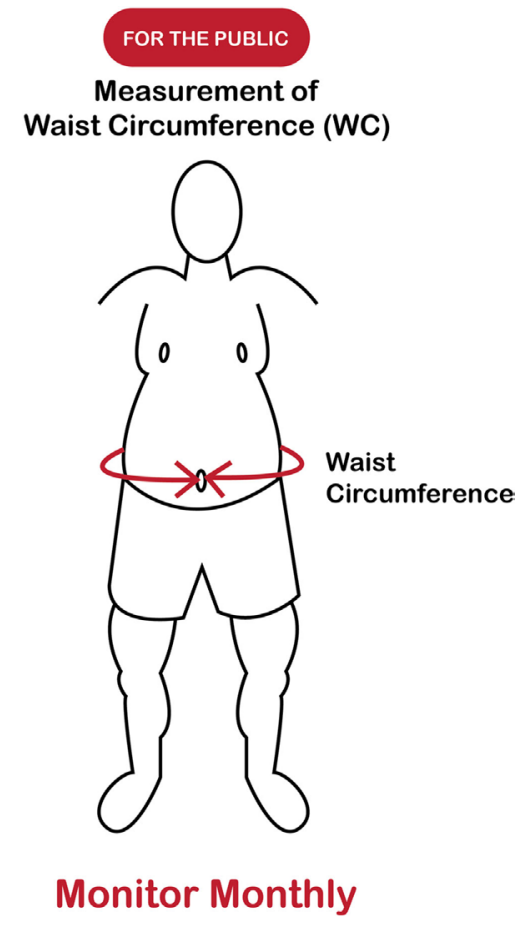

FIGURE 3 | Measuring overfat (for the public).

\section{Abdominal Overfat}

The increasing rates of overfat people are due in great part to increased incidence of abdominal obesity in adults and children $(61,89)$. Other terminologies used for this condition include visceral obesity, visceral adiposity, android obesity, central obesity, the hypertriglyceridemic waist, and others. Since the problem can occur in people who are not obese, we suggest the term abdominal overfat as a simplified one that broadly defines the specific problem of excess abdominal fat.

Two separate components of abdominal fat include visceral adipose tissue and subcutaneous adipose tissue, the former being associated with more adverse risk factor profiles than the latter $(45,90)$. Although total adiposity is strongly associated with cardiometabolic risk, it is becoming increasingly clear that visceral adipose tissue is a stronger correlate of risk than BMI, WC, or abdominal subcutaneous fat (91), and more strongly associated with insulin resistance, dyslipidemia, and atherosclerosis than peripheral obesity (92).

The recognition that abdominal overfat has separate and more severe health effects is not new (93-106). Prospective epidemiological studies have demonstrated the power of abdominal overfat to predict premature death in conjunction with various cardiometabolic-related chronic diseases in both men and women (107). Numerous studies more recently reported secular increases in WC in men and women in the US, England, Australia, Finland, and the Netherlands (108-115).

In our estimation of overfat children, we considered studies that measured BFP and WHtR. BFP measures may represent a

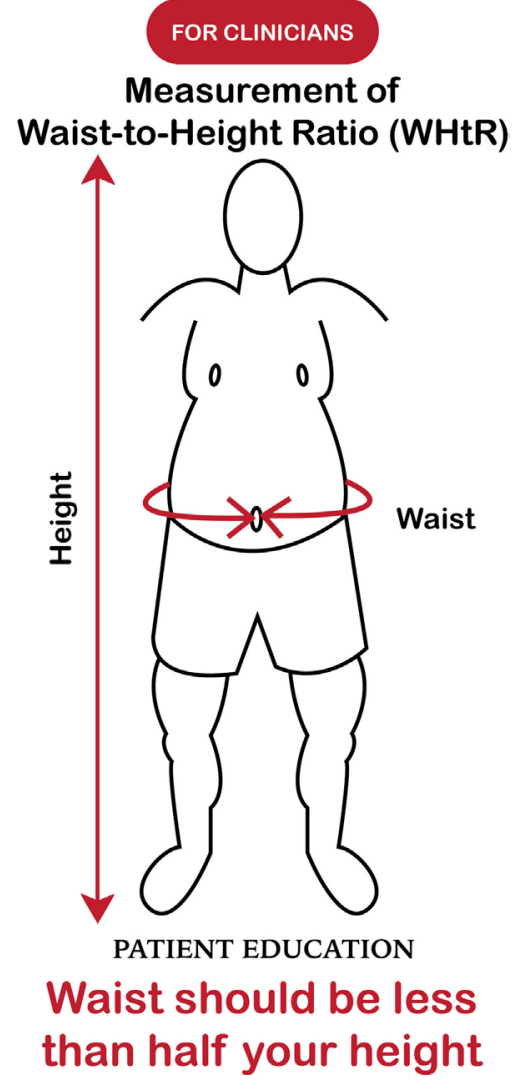

FIGURE 4 | Measuring overfat (for healthcare practitioners).

reasonable method of estimating the population of normal-weight non-obese children, as excess body fat can exist in those with a BMI $<25$ (116). Based on the WHtR ( $<0.5$ vs. $\geq 0.5)$, $37 \%$ of normal-weight non-obese children had at least one cardiometabolic health risk factor (associated with WC, triglycerides, and high blood pressure), $13.5 \%$ had at least two risk factors, and $0.3 \%$ had three risk factors (117). Moreover, as with adults, abdominal overfat is associated with greater health risks in children $(118,119)$.

In recent decades, the prevalence of childhood abdominal overfat has increased more quickly than the prevalence of obesity as defined by BMI $(120,121)$. While, as in adults, research shows an unexpected plateauing of childhood obesity rates in some developed countries (122), increased rates of abdominal overfat appear to have maintained the overall growth rate of the overfat pandemic. In addition, extreme obesity in children continues to increase despite the fact that rates for lower obesity categories are leveling or even declining (123). In light of the clear limitations of the BMI described herein, the WHtR may be the single best clinical indicator of health risk as it can be used throughout childhood, into adult life, as well as throughout the world (in all ethnic groups). (See Figures 3 and 4) (124, 125).

Additionally, as an important part of clinical practice, the routine measurement of WC is consistent with current recommendations for the prevention, control, and management of overfat in patients (126). 
TABLE 2 | Percentages of overfat subpopulations of the 30 most developed countries according to the Human Development Index.

\begin{tabular}{|c|c|c|c|c|}
\hline \multirow{3}{*}{ Country } & \multicolumn{3}{|c|}{ Overfat (\%) } & \\
\hline & & & \multicolumn{2}{|c|}{ Children } \\
\hline & Males & Females & Males & Females \\
\hline Norway & 78.4 (75.7-81) & $67.3(64.4-70.2)$ & 42.7 (39.8-45.6) & $38.2(35.6-40.9)$ \\
\hline Australia & 88.2 (85.6-90.5) & 76.1 (73.4-78.9) & $47(44-50.6)$ & $45.2(42.1-48.7)$ \\
\hline Switzerland & 76.6 (73.7-79.4) & $59.9(57-62.9)$ & $43.3(40-47)$ & $38.4(35.6-41.6)$ \\
\hline Denmark & 79.2 (76.5-81.9) & $64.7(61.7-67.7)$ & $42.3(39.4-45.7)$ & $41.6(38-45.4)$ \\
\hline Netherlands & $73.2(71.1-75.4)$ & $64.9(62.3-67.5)$ & 40.9 (38.3-43.9) & $38.3(35.6-41.1)$ \\
\hline Germany & 84.3 (81.9-86.8) & $69(66.5-71.4)$ & $43.1(40-46.4)$ & $41.6(38.5-44.7)$ \\
\hline Ireland & 86.4 (83.9-88.8) & 70.9 (68.3-73.6) & $49.2(45.8-53.4)$ & $48.7(45.1-52.7)$ \\
\hline United States & $90.9(89.2-92.5)$ & $81.9(79.8-83.8)$ & $51.4(49-54)$ & $51.9(49.4-54.7)$ \\
\hline Canada & $84.5(82-87)$ & $68.5(65.9-71.1)$ & $48.1(45-51.3)$ & $44.2(41.3-47.7)$ \\
\hline New Zealand & 91.4 (89.6-93.3) & $80(77.8-82.2)$ & $52.2(48.6-55.9)$ & $50.9(47.5-54.8)$ \\
\hline Singapore & $64.3(61.4-67.1)$ & $52.5(50-55.1)$ & $43.5(40.1-46.9)$ & $35.5(33.1-38.2)$ \\
\hline Sweden & $78.2(75.6-81)$ & $65.8(63.2-68.5)$ & $43(40.1-46)$ & $41.5(38.7-44.7)$ \\
\hline United Kingdom & 86.6 (85.3-88) & $77.2(75.7-78.6)$ & $48.7(46.4-51.1)$ & $51.4(49-54.1)$ \\
\hline Iceland & 93.6 (91.3-95.8) & 80.9 (78-83.8) & 49 (45.3-52.8) & $45.2(41.9-48.8)$ \\
\hline South Korea & $56.9(55.1-58.8)$ & $47.2(45.6-48.9)$ & $43.8(40.5-47.1)$ & $35.4(33.1-37.9)$ \\
\hline Israel & $80.4(77.6-83.2)$ & 72.7 (69.6-75.6) & $53.6(49.6-58.2)$ & $48.8(44.8-53.3)$ \\
\hline Luxembourg & 78 (75.1-80.8) & $64.4(61.6-67.2)$ & $51.9(47.9-56)$ & $39.9(36.7-43.3)$ \\
\hline Japan & $48.9(47.1-50.7)$ & $37.6(36.5-38.9)$ & $37.9(35.8-40.2)$ & $34.6(32.4-36.8)$ \\
\hline Belgium & 78 (75.2-80.8) & 67.1 (64.3-69.9) & $43.1(40.3-46.2)$ & $41(38.2-44)$ \\
\hline France & 75.9 (73.2-78.7) & $62.8(60-65.7)$ & $42.5(39.4-45.9)$ & $38.2(35.5-40.9)$ \\
\hline Austria & 79.7 (77-82.3) & $62.8(60.1-65.4)$ & $41.5(38.5-44.7)$ & $38.5(35.7-41.6)$ \\
\hline Finland & $82.2(79.5-84.9)$ & 70.4 (67.5-73.2) & $48.6(44.9-52.4)$ & $43.3(39.9-47.2)$ \\
\hline Slovenia & 85.1 (82.3-87.6) & $72.1(69.1-74.8)$ & 55.7 (52-59.5) & $46.2(42.9-49.5)$ \\
\hline Spain & $82.3(80-84.9)$ & 66.5 (63.7-68.9) & $50.2(46.5-53.8)$ & $46(42.4-49.6)$ \\
\hline Italy & $78.3(75.5-81.1)$ & $61.4(58.9-64.2)$ & $52.5(49-56.5)$ & $46.5(43.2-50.1)$ \\
\hline Czech Republic & 85.5 (82.9-88.2) & 70 (67.2-72.7) & $44.9(41.7-48.9)$ & $40.2(37.2-43.2)$ \\
\hline Greece & 91.4 (88.9-93.7) & $71.1(68.2-74)$ & $56.3(52.2-60.3)$ & $51.3(47.5-55.3)$ \\
\hline Estonia & 79.3 (76.5-82) & $74.3(71.5-77.2)$ & $46.6(42.8-50.4)$ & $43.6(40.2-47.4)$ \\
\hline Brunei & $43.3(41.2-45.2)$ & $37.9(36.2-39.8)$ & $29.3(28.1-30.6)$ & $27.8(26.7-29)$ \\
\hline Cyprus & $87.8(85-90.6)$ & $72.1(69.1-75.1)$ & $48.3(44.5-52.2)$ & $44.7(41.1-48.4)$ \\
\hline
\end{tabular}

\section{ESTIMATING OVERFAT POPULATIONS}

We estimated the incidence of overfat in 30 developed nations listed in Table 2 using the HDI described by the United Nations Development Programme's Human Development Report for 2014 (see Figure 5). Accurate estimations of the prevalence of overfat populations is challenging, especially considering that appropriate BFP analyses (e.g., X-ray absorptiometry, DXA) are not common. However, a number of studies have been helpful in differentiating normal-weight and non-obese but overfat individuals from those who are overweight or obese $(8,9,127)$ As such, in addition to the estimations of overweight and obese populations (4), we also considered individuals with increased BFP and or WC/WHtR in normal-weight non-obese adults with signs of cardiometabolic impairments as discussed above, including two national studies in the UK and US, which provided useful data on children who were normal weight and not obese. Griffiths et al. (128) showed that $17.6 \%$ of normal-weight non-obese boys and $17.3 \%$ of normal-weight non-obese girls who exceeded a WHtR of 0.5 were considered "at risk," as compared with children who were overweight or obese and above the 85th percentile (128). Flegal et al. (116) estimated the prevalence of high adiposity for children below the 85th percentile using dual-energy X-ray absorptiometry to estimate BFP and found that a high number of children with normal BMI had high

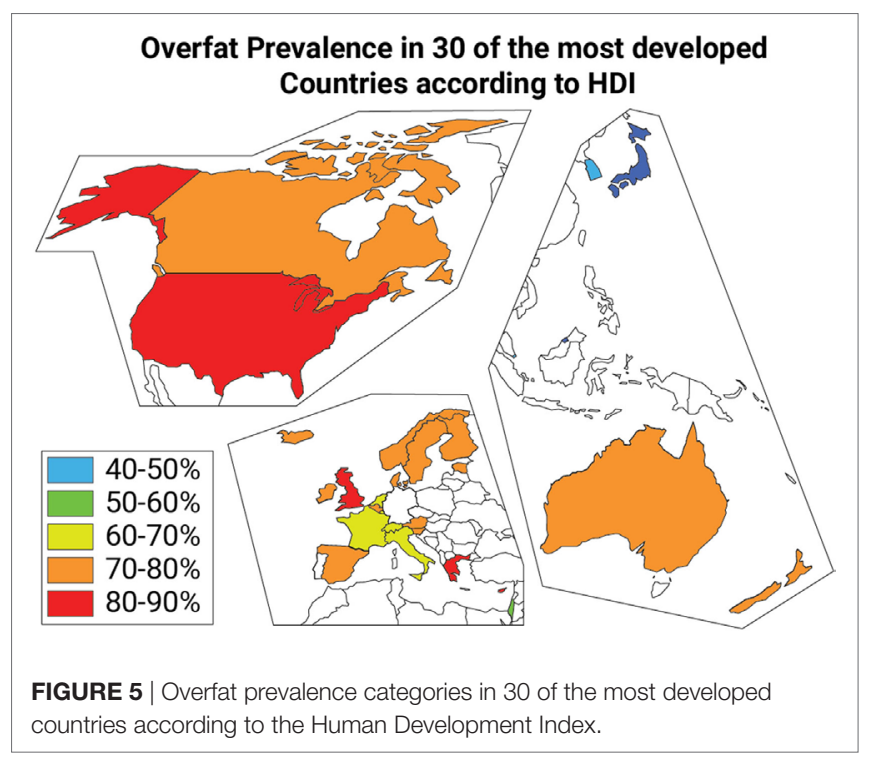

adiposity $-35 \%$ of children within the 65 th percentile cutoff and $24 \%$ of children within the 70th percentile cutoff.

Our estimates did not include normal-weight non-obese people who had high fat mass but only early signs of cardiometabolic 
dysfunction (such as prediabetes or prehypertension), because insufficient data were available. However, the numbers of individuals in this category could be significant. For example, prediabetes in the US has risen to $\sim 34 \%$ in the population even among those who are normal weight (129). Prehypertension is also not uncommon and increases the risk for incident hypertension and cardiovascular mortality (130).

Since data for overfat subpopulations was not uniformly available for the same year, we used the most recent data available in order to produce our estimates. Ng et al. (4) used a similar strategy to provide estimates of various populations at risk of metabolic disease, as do other large-scale epidemiological studies cited throughout our paper. The most recent data, obtained from the Centers for Disease Control and Prevention (CDC) website shows that $71 \%$ of US adults were overweight or obese (131). However, for continuity, our analysis for all countries used data from $\mathrm{Ng}$ et al. (4), which shows overweight and obesity in US adults at $66 \%$. Had we used the more recent CDC data, our estimate for the US would likely have yielded much higher percentages of overfat.

In our estimation of overfat adults and children, it was not possible to precisely quantify all categories of overfat individuals. One limitation of our estimates is that we may have underrated those 70-80 years and older with sarcopenic overfat, and those who were institutionalized or otherwise in poor health, as these individuals are usually not part of community and other population studies. In addition, younger children up to 5 years are often not counted in population studies. Children between the ages of 5 and 14 years may have already been overfat when entering kindergarten (132). The use of WC and WHtR often use relatively high cutoff points and may miss early conditions of overfat potentially making our estimates conservative. Likewise, BFP in most adult studies typically use relatively high cutoff points recommended by the WHO of 30 for men and 35 for women, furthering the risk of underreporting overfat individuals.

The importance of our review includes increasing awareness of the overfat pandemic in developed countries, whose rates are relatively higher than worldwide percentages. In addition, we have emphasized the continued increase of overfat populations despite the appearance of a leveling of both overweight and obesity in some developed countries. Of greater awareness is the concern that the largest increase in overfat is due to both increases in the prevalence of abdominal overfat and the increasing average size

\section{REFERENCES}

1. Maffetone PB, Rivera-Dominguez I, Laursen PB. Overfat and underfat: new terms and definitions long overdue. Front Public Health (2016) 4:279. doi:10.3389/fpubh.2016.00279

2. WHO. Obesity: preventing and managing the global epidemic. Report of a WHO consultation. World Health Organ Tech Rep Ser (2000) 894:i-xii, 1-253. doi:10.1017/S0021932003245508

3. WHO. Global Economic Burden of Noncommunicable Diseases (September 2011). (2011). Available from: http://apps.who.int/medicinedocs/en/d/Js18806en/

4. Ng M, Fleming T, Robinson M, Thomson B, Graetz N, Margono C, et al. Global, regional, and national prevalence of overweight and obesity in children and adults during 1980-2013: a systematic analysis for the global burden of disease study 2013. Lancet (2014) 384(9945):766-81. doi:10.1016/S0140-6736(14)60460-8

5. Romero-Corral A, Somers VK, Sierra-Johnson J, Korenfeld Y, Boarin S, Korinek J, et al. Normal weight obesity: a risk factor for cardiometabolic of WCs, as abdominal overfat is the most serious form of the overfat pandemic. Bringing these factors into evidence could help lead to action in reducing the overfat pandemic.

Continued debate on how best to measure obesity and body fat may miss an important clinical point. That being, that most clinicians in the course of their normal in-office assessments usually know if the patient in front of them has too much body fat. Clinicians should not have to wait for the latest consensus or for a patients' fat mass to reach a pre-established cutoff in order for them to implement appropriate lifestyle strategies to reduce excess body fat in their patients.

In the future, an accurate evaluation of the prevalence of overfat will need to include a consistent and accurate measurement of BFP across populations, as well as a general consensus on cutoffs along with factors associated with fat distribution, and the relationships with health risks. These evaluations of overfat should be based on epidemiologic studies with long-term follow-up and information on overfat-related comorbidities and mortality. However, this should not be done at the expense of population-wide effective remedies to reduce the incidence of the overfat pandemic and to prevent its growth by addressing the problem as it emerges in children.

\section{CONCLUSION}

The estimate of overfat in the world's 30 top developed nations is substantially higher than the prevalence of overweight and obese adults and children worldwide and stresses the seriousness of the overfat pandemic. Regardless of BMI values, overfat individuals have excess body fat, a high degree of cardiometabolic dysregulation that can promote disease risk factors and chronic disease, increased morbidity and mortality, reduced quality of life, and pose a rising economic burden. As an unfulfilled public health action, it is crucial to clinically identify individuals who are overfat in order to implement successful treatment and prevention strategies.

\section{AUTHOR CONTRIBUTIONS}

PM-originator of ideas, data collection, analysis, critical thinking, writing of the manuscript. IR-D—contributed to ideas, data analysis, figure and table writing, critical thinking, contributed to the writing. PL-contributed to ideas, critical thinking, writing of the manuscript.

dysregulation and cardiovascular mortality. Eur Heart J (2010) 31:737-46. doi:10.1093/eurheartj/ehp487

6. Poirier P, Giles TD, Bray GA, Hong Y, Stern JS, Pi-Sunyer FX, et al. Obesity and cardiovascular disease: pathophysiology, evaluation, and effect of weight loss. Circulation (2006) 113(6):898-918. doi:10.1161/CIRCULATIONAHA.106.171016

7. Freedman DS, Ford ES. Are the recent secular increases in the waist circumference of adults independent of changes in BMI? Am J Clin Nutr (2015) 101(3):425-31. doi:10.3945/ajcn.114.094672

8. Romero-Corral A, Somers VK, Sierra-Johnson J, Thomas RJ, Collazo-Clavell ML, Korinek J, et al. Accuracy of body mass index in diagnosing obesity in the adult general population. Int J Obes (2008) 32(6):959-66. doi:10.1038/ijo.2008.11

9. Okorodudu D, Jumean M, Montori VM, Romero-Corral A, Somers VK, Erwin PJ, et al. Diagnostic performance of body mass index to identify obesity as defined by body adiposity: a systematic review and meta-analysis. Int J Obes (2010) 34(5):791-9. doi:10.1038/ijo.2010.5 
10. Ruderman N, Chisholm D, Pi-Sunyer X, Schneider S. The metabolically obese, normal-weight individual revisited. Diabetes (1998) 47(5):699-713. doi:10.2337/diabetes.47.5.699

11. Ruderman N, Berchtold P, Schneider S. Obesity-associated disorders in normal-weight individuals: some speculations. Int J Obes (1981) 6:151-7.

12. Hollenbeck C, Reaven GM. Variations in insulin-stimulated glucose uptake in healthy individuals with normal glucose tolerance. J Clin Endocrinol Metab (1987) 64(6):1169-73. doi:10.1210/jcem-64-6-1169

13. Reaven GM. Role of insulin resistance in human disease. Diabetes (1988) 37(12):1595-607. doi:10.2337/diabetes.37.12.1595

14. Zavaroni I, Bonora E, Pagliara M, Dall'Aglio E, Luchetti L, Buonanno G, et al. Risk factors for coronary artery disease in healthy persons with hyperinsulinemia and normal glucose tolerance. N Engl J Med (1989) 320(11):702-6. doi:10.1056/NEJM198903163201105

15. Tomiyama A, Hunger J, Nguyen-Cuu J, Wells C. Misclassification of cardiometabolic health when using body mass index categories in NHANES 2005-2012. Int J Obes (2016) 40(5):883-6. doi:10.1038/ijo.2016.17

16. Weiss R, Bremer AA, Lustig RH. What is metabolic syndrome, and why are children getting it? Ann N Y Acad Sci (2013) 1281(1):123-40. doi:10.1111/ nyas. 12030

17. Stenholm S, Harris TB, Rantanen T, Visser M, Kritchevsky SB, Ferrucci L. Sarcopenic obesity-definition, etiology and consequences. Curr Opin Clin Nutr Metab Care (2008) 11(6):693. doi:10.1097/MCO.0b013e328312c37d

18. Koh-Banerjee P, Wang Y, Hu FB, Spiegelman D, Willett WC, Rimm EB. Changes in body weight and body fat distribution as risk factors for clinical diabetes in US men. Am J Epidemiol (2004) 159(12):1150-9. doi:10.1093/aje/ kwh167

19. Suganami T, Ogawa Y. Role of chronic inflammation in adipose tissue in the pathophysiology of obesity. Abstract. Jpn J Clin Med (2013) 71(2):225-30.

20. Pokharel Y, Basra S, Lincoln AE, Tucker AM, Nambi V, Nasir K, et al. Association of body mass index and waist circumference with subclinical atherosclerosis in retired NFL players. South Med J (2014) 107(10):633-9. doi:10.14423/SMJ.0000000000000173

21. De Lorenzo A, Martinoli R, Vaia F, Di Renzo L. Normal weight obese (NWO) women: an evaluation of a candidate new syndrome. Nutr Metab Cardiovasc Dis (2006) 16(8):513-23. doi:10.1016/j.numecd.2005.10.010

22. Oliveros E, Somers VK, Sochor O, Goel K, Lopez-Jimenez F. The concept of normal weight obesity. Prog Cardiovasc Dis (2014) 56(4):426-33. doi:10.1016/j.pcad.2013.10.003

23. Prospective Studies Collaboration, Whitlock G, Lewington S, Sherliker P, Clarke R, Emberson J, et al. Body-mass index and cause-specific mortality in 900000 adults: collaborative analyses of 57 prospective studies. Lancet (2009) 373(9669):1083-96. doi:10.1016/S0140-6736(09)60318-4

24. Hung SP, Chen CY, Guo FR, Chang CI, Jan CF. Combine body mass index and body fat percentage measures to improve the accuracy of obesity screening in young adults. Obes Res Clin Pract (2017) 11(1):11-8. doi:10.1016/j. orcp.2016.02.005

25. Deurenberg P, Yap M, Van Staveren WA. Body mass index and percent body fat: a meta analysis among different ethnic groups. Int J Obes (1998) 22:1164-71. doi:10.1038/sj.ijo.0800741

26. Deurenberg-Yap M, Deurenberg P. Is a re-evaluation of WHO body mass index cut-off values needed? The case of Asians in Singapore. Nutr Rev (2003) 61(Suppl 5):S80-7. doi:10.1301/nr.2003.may.S80-S87

27. Pan WH, Yeh WT. How to define obesity? Evidence-based multiple action points for public awareness, screening, and treatment: an extension of AsianPacific recommendations. Asia Pac J Clin Nutr (2008) 17(3):370-4.

28. Giorgino F, Laviola L, Eriksson JW. Regional differences of insulin action in adipose tissue: insights from in vivo and in vitro studies. Acta Physiol Scand (2005) 183(1):13-30. doi:10.1111/j.1365-201X.2004.01385.x

29. Park MH, Kim DH, Lee EK, Kim ND, Im DS, Lee J, et al. Age-related inflammation and insulin resistance: a review of their intricate interdependency. Arch Pharm Res (2014) 37(12):1507-14. doi:10.1007/s12272-014-0474-6

30. Jiao $\mathrm{P}, \mathrm{Xu} \mathrm{H}$. Adipose inflammation: cause or consequence of obesity-related insulin resistance. Diabetes Metab Syndr Obes (2008) 1:25-31. doi:10.2147/ DMSO.S4180

31. McArdle MA, Finucane OM, Connaughton RM, McMorrow AM, Roche HM. Mechanisms of obesity-induced inflammation and insulin resistance: insights into the emerging role of nutritional strategies. Front Endocrinol (2013) 4:52. doi:10.3389/fendo.2013.00052
32. Cornier M, Després J, Davis N, Grossniklaus DA, Klein S, Lamarche B, et al. Assessing adiposity: a scientific statement from the American Heart Association. Circulation (2011) 124(18):1996-2019. doi:10.1161/ CIR.0b013e318233bc6a

33. Gallagher D, Heymsfield SB, Heo M, Jebb SA, Murgatroyd PR, Sakamoto Y. Healthy percentage body fat ranges: an approach for developing guidelines based on body mass index. Am J Clin Nutr (2000) 72(3):694-701.

34. Cole TJ, Bellizzi MC, Flegal KM, Dietz WH. Establishing a standard definition for child overweight and obesity worldwide: international survey. $B M J$ (2000) 320(7244):1240. doi:10.1136/bmj.320.7244.1240

35. Jahan S, Jespersen E, Mukherjee S, Kovacevic M, Bonini A, Calderon C, et al. Human Development Report 2015: Work for Human Development. New York, NY: UNDP (2015).

36. UN. United Nations Population Division-World Population Prospects: The 2010 Revision.(2011).Availablefrom:http://www.prb.org/publications/Datasheets/ 2012/world-population-data-sheet/fact-sheet-world-population.aspx

37. Meigs JB, Wilson PW, Fox CS, Vasan RS, Nathan DM, Sullivan LM, et al. Body mass index, metabolic syndrome, and risk of type 2 diabetes or cardiovascular disease. J Clin Endocrinol Metab (2006) 91(8):2906-12. doi:10.1210/ jc.2006-0594

38. Obesity and Overweight. Fact Sheet No. 311. (2013). Available from: http:// www.who.int/mediacentre/factsheets/fs311/en/

39. Smith KB, Smith MS. Obesity statistics. Prim Care (2016) 43(1):121-35. doi:10.1016/j.pop.2015.10.001

40. Wilson P, Meigs J. Cardiometabolic risk: a Framingham perspective. Int J Obes (2008) 32:S17-20. doi:10.1038/ijo.2008.30

41. Stino AM, Smith AG. Peripheral neuropathy in prediabetes and the metabolic syndrome. J Diabetes Investig (2017). doi:10.1111/jdi.12650

42. Magnussen CG, Smith KJ. Pediatric blood pressure and adult preclinical markers of cardiovascular disease. Clin Med Insights Blood Disord (2016) 9:1. doi:10.4137/CMBD.S18887

43. Madeira FB, Silva AA, Veloso HF, Goldani MZ, Kac G, Cardoso VC, et al. Normal weight obesity is associated with metabolic syndrome and insulin resistance in young adults from a middle-income country. PLoS One (2013) 8(3):e60673. doi:10.1371/journal.pone.0060673

44. Nagaretani H, Nakamura T, Funahashi T, Kotani K, Miyanaga M, Tokunaga K, et al. Visceral fat is a major contributor for multiple risk factor clustering in Japanese men with impaired glucose tolerance. Diabetes Care (2001) 24(12):2127-33. doi:10.2337/diacare.24.12.2127

45. Fox CS, Massaro JM, Hoffmann U, Pou KM, Maurovich-Horvat P, Liu CY, et al. Abdominal visceral and subcutaneous adipose tissue compartments. Circulation (2007) 116(1):39-48. doi:10.1161/ CIRCULATIONAHA.106.675355

46. Rutter MK, Parise H, Benjamin EJ, Levy D, Larson MG, Meigs JB, et al. Impact of glucose intolerance and insulin resistance on cardiac structure and function. Circulation (2003) 107(3):448-54. doi:10.1161/01. CIR.0000045671.62860.98

47. Meigs JB, Larson MG, D’Agostino RB, Levy D, Clouse ME, Nathan DM, et al. Coronary artery calcification in type 2 diabetes and insulin resistance. Diabetes Care (2002) 25(8):1313-9. doi:10.2337/diacare.25.8.1313

48. Park MH, Falconer C, Viner RM, Kinra S. The impact of childhood obesity on morbidity and mortality in adulthood: a systematic review. Obes Rev (2012) 13(11):985-1000. doi:10.1111/j.1467-789X.2012.01015.x

49. Field AE, Cook NR, Gillman MW. Weight status in childhood as a predictor of becoming overweight or hypertensive in early adulthood. Obes Res (2005) 13(1):163-9. doi:10.1038/oby.2005.21

50. Krassas G, Tzotzas T. Do obese children become obese adults: childhood predictors of adult disease. Pediatr Endocrinol Rev (2004) 1(3):455-9.

51. Singh AS, Mulder C, Twisk JW, van Mechelen W, Chinapaw MJ. Tracking of childhood overweight into adulthood: a systematic review of the literature. Obes Rev (2008) 9(5):474-88. doi:10.1111/j.1467-789X.2008.00475.x

52. Schubert CM, Sun SS, Burns TL, Morrison JA, Huang TT. Predictive ability of childhood metabolic components for adult metabolic syndrome and type 2 diabetes. J Pediatr (2009) 155(3):S6.e1-7. doi:10.1016/j.jpeds.2009.04.048

53. Baker JL, Olsen LW, Sorensen TI. Childhood body-mass index and the risk of coronary heart disease in adulthood. J Vasc Surg (2008) 47(4):893-4. doi:10.1016/j.jvs.2008.02.015

54. Meigs JB, D’Agostino RB Sr., Wilson PW, Cupples LA, Nathan DM, Singer DE. Risk variable clustering in the insulin resistance syndrome: the 
Framingham offspring study. Diabetes (1997) 46(10):1594-600. doi:10.2337/ diacare.46.10.1594

55. Guillemot-Legris O, Muccioli GG. Obesity-induced neuroinflammation: beyond the hypothalamus. Trends Neurosci (2017) 40(4):237-53. doi:10.1016/j.tins.2017.02.005

56. Lean $\mathrm{M}, \mathrm{Han} \mathrm{T}$, Seidell J. Impairment of health and quality of life in people with large waist circumference. Lancet (1998) 351(9106):853-6. doi:10.1016/ S0140-6736(97)10004-6

57. Scappaticcio L, Maiorino MI, Bellastella G, Giugliano D, Esposito K. Insights into the relationships between diabetes, prediabetes, and cancer. Endocrine (2016) 56(2):231-9. doi:10.1007/s12020-016-1216-y

58. Lauby-Secretan B, Scoccianti C, Loomis D, Grosse Y, Bianchini F, Straif K, et al. Body fatness and cancer - viewpoint of the IARC working group. $N$ Engl J Med (2016) 375(8):794-8. doi:10.1056/NEJMsr1606602

59. Copson ER, Cutress RI, Maishman T, Eccles BK, Gerty S, Stanton L, et al. Obesity and the outcome of young breast cancer patients in the UK: the POSH study. Ann Oncol (2015) 26(1):101-12. doi:10.1093/annonc/mdu509

60. Department of Health N. National Child Measurement Programme: England, 2009/10 School Year. London: The NHS Information Centre (2010).

61. Ford ES, Maynard LM, Li C. Trends in mean waist circumference and abdominal obesity among US adults, 1999-2012. JAMA (2014) 312(11):1151-3. doi:10.1001/jama.2014.8362

62. Ogden CL, Carroll MD, Kit BK, Flegal KM. Prevalence of childhood and adult obesity in the United States, 2011-2012. JAMA (2014) 311(8):806-14. doi:10.1001/jama.2014.732

63. Flegal KM, Carroll MD, Kit BK, Ogden CL. Prevalence of obesity and trends in the distribution of body mass index among US adults, 1999-2010. JAMA (2012) 307(5):491-7. doi:10.1001/jama.2012.39

64. Rokholm B, Baker JL, Sørensen TIA. The levelling off of the obesity epidemic since the year 1999 - a review of evidence and perspectives. Obes Rev (2010) 11(12):835-46. doi:10.1111/j.1467-789X.2010.00810.x

65. Ladabaum U, Mannalithara A, Myer PA, Singh G. Obesity, abdominal obesity, physical activity, and caloric intake in US adults: 1988 to 2010. Am J Med (2014) 127(8):717-27.e12. doi:10.1016/j.amjmed.2014.02.026

66. Flegal KM, Kruszon-Moran D, Carroll MD, Fryar CD, Ogden CL. Trends in obesity among adults in the United States, 2005 to 2014. JAMA (2016) 315(21):2284-91. doi:10.1001/jama.2016.6458

67. Basterra-Gortari FJ, Beunza JJ, Bes-Rastrollo M, Toledo E, García-López M, Martínez-González MA. Increasing trend in the prevalence of morbid obesity in Spain: from 1.8 to 6.1 per thousand in 14 years. Rev Esp Cardiol (2011) 64(5):424-6. doi:10.1016/j.recesp.2010.06.010

68. Sturm R, Hattori A. Morbid obesity rates continue to rise rapidly in the United States. Int J Obes (2013) 37(6):889-91. doi:10.1038/ijo.2012.159

69. World Obesity Federation. World Obesity Day Statistics. (2015). Available from: http://www.worldobesity.org/what-we-do/action-initiative/aiprogrammes/ world-obesity-day/statistics/

70. Johnson W, Li L, Kuh D, Hardy R. How has the age-related process of overweight or obesity development changed over time? Co-ordinated analyses of individual participant data from five United Kingdom birth cohorts. PLoS Med (2015) 12(5):e1001828. doi:10.1371/journal.pmed.1001828

71. Kraschnewski JL, Sciamanna CN, Stuckey HL, Chuang CH, Lehman EB, Hwang KO, et al. A silent response to the obesity epidemic: decline in US physician weight counseling. Med Care (2013) 51(2):186-92. doi:10.1097/ MLR.0b013e3182726c33

72. Yates EA, Macpherson AK, Kuk JL. Secular trends in the diagnosis and treatment of obesity among US adults in the primary care setting. Obesity (2012) 20(9):1909-14. doi:10.1038/oby.2011.271

73. Snook KR, Hansen AR, Duke CH, Finch KC, Hackney AA, Zhang J. Change in percentages of adults with overweight or obesity trying to lose weight, 1988-2014. JAMA (2017) 317(9):971-3. doi:10.1001/jama.2016.20036

74. Wang B, Zhuang R, Luo X, Yin L, Pang C, Feng T, et al. Prevalence of metabolically healthy obese and metabolically obese but normal weight in adults worldwide: a meta-analysis. Horm Metab Res (2015) 47(11):839-45. doi:10. 1055/s-0035-1559767

75. Ferrannini E, Natali A, Bell P, Cavallo-Perin P, Lalic N, Mingrone G. Insulin resistance and hypersecretion in obesity. European Group for the Study of Insulin Resistance (EGIR). JClin Invest (1997) 100(5):1166. doi:10.1172/ JCI119628
76. Bonora E, Kiechl S, Willeit J, Oberhollenzer F, Egger G, Targher G, et al. Prevalence of insulin resistance in metabolic disorders: the Bruneck study. Diabetes (1998) 47(10):1643-9. doi:10.2337/diabetes.47.10.1643

77. Brochu M, Tchernof A, Dionne IJ, Sites CK, Eltabbakh GH, Sims EA, et al. What are the physical characteristics associated with a normal metabolic profile despite a high level of obesity in postmenopausal women? JClin Endocrinol Metab (2001) 86(3):1020-5. doi:10.1210/jcem.86.3.7365

78. Karelis AD, Faraj M, Bastard JP, St-Pierre DH, Brochu M, Prud'homme D, et al. The metabolically healthy but obese individual presents a favorable inflammation profile. JClin Endocrinol Metab (2005) 90(7):4145-50. doi:10.1210/jc.2005-0482

79. Oflaz H, Ozbey N, Mantar F, Genchellac H, Mercanoglu F, Sencer E, et al. Determination of endothelial function and early atherosclerotic changes in healthy obese women. Diabetes Nutr Metab (2003) 16(3):176-81.

80. Benjamin EJ, Larson MG, Keyes MJ, Mitchell GF, Vasan RS, Keaney JF Jr, et al. Clinical correlates and heritability of flow-mediated dilation in the community. Circulation (2004) 109(5):613-9. doi:10.1161/01.CIR. 0000112565.60887.1E

81. Bloom D, Cafiero E, Jané-Llopis E, Abrahams-Gessel S, Bloom LR, Fathima S, et al. The global economic burden of noncommunicable diseases (2011). Geneva: World Economic Forum.

82. Elliott KR, Harmatz JS, Zhao Y, Greenblatt DJ. Body size changes among national collegiate athletic association New England division III football players, 1956-2014: comparison with age-matched population controls. J Athl Train (2016) 51(5):373-81. doi:10.4085/1062-6050-51.5.14

83. Yamamoto JB, Yamamoto BE, Yamamoto PP, Yamamoto LG. Epidemiology of college athlete sizes, 1950s to current. Res Sports Med (2008) 16(2):111-27. doi:10.1080/15438620802103320

84. Gasier HG, Hughes LM, Young CR, Richardson AM. Comparison of body composition assessed by dual-energy X-ray absorptiometry and BMI in current and former US navy service members. PLoS One (2015) 10(7):e0132157. doi:10.1371/journal.pone.0132157

85. Grier T, Canham-Chervak M, Sharp M, Jones BH. Does body mass index misclassify physically active young men. Prev Med Rep (2015) 2:483-7. doi:10.1016/j.pmedr.2015.06.003

86. Ali S, Garcia JM. Sarcopenia, cachexia and aging: diagnosis, mechanisms and therapeutic options-a mini-review. Gerontology (2014) 60(4):294-305. doi: $10.1159 / 000356760$

87. Sakuma K, Yamaguchi A. Sarcopenic obesity and endocrinal adaptation with age. Int J Endocrinol (2013) 2013:204164. doi:10.1155/2013/204164

88. Muscaritoli M, Anker S, Argiles J, Aversa Z, Bauer JM, Biolo G, et al. Consensus definition of sarcopenia, cachexia and pre-cachexia: joint document elaborated by special interest groups (SIG) "cachexia-anorexia in chronic wasting diseases" and "nutrition in geriatrics". Clin Nutr (2010) 29(2):154-9. doi:10.1016/j.clnu.2009.12.004

89. de Moraes AC, Fadoni RP, Ricardi LM, Souza TC, Rosaneli CF, Nakashima AT, et al. Prevalence of abdominal obesity in adolescents: a systematic review. Obes Rev (2011) 12(2):69-77. doi:10.1111/j.1467-789X.2010.00753.x

90. Despres J, Lemieux S, Lamarche B, Prud'homme D, Moorjani S, Brun LD, et al. The insulin resistance-dyslipidemic syndrome: contribution of visceral obesity and therapeutic implications. Int J Obes Relat Metab Disord (1995) 19:S76.

91. Porter SA, Massaro JM, Hoffmann U, Vasan RS, O’Donnel CJ, Fox CS. Abdominal subcutaneous adipose tissue: a protective fat depot? Diabetes Care (2009) 32(6):1068-75. doi:10.2337/dc08-2280

92. Scherzer R, Shen W, Bacchetti P, Kotler D, Lewis CE, Shlipak MG, et al. Simple anthropometric measures correlate with metabolic risk indicators as strongly as magnetic resonance imaging-measured adipose tissue depots in both HIV-infected and control subjects. Am J Clin Nutr (2008) 87(6):1809-17.

93. Vague J. The degree of masculine differentiation of obesities a factor determining predisposition to diabetes, atherosclerosis, gout, and uric calculous disease. Am J Clin Nutr (1956) 4(1):20-34.

94. Kissebah AH, Vydelingum N, Murray R, Evans DJ, Hartz AJ, Kalkhoff RK, et al. Relation of body fat distribution to metabolic complications of obesity. J Clin Endocrinol Metab (1982) 54(2):254-60. doi:10.1210/jcem-54-2-254

95. Krotkiewski M, Björntorp P, Sjöström L, Smith U. Impact of obesity on metabolism in men and women. Importance of regional adipose tissue distribution. J Clin Invest (1983) 72(3):1150. doi:10.1172/JCI111040 
96. Ohlson LO, Larsson B, Svärdsudd K, Welin L, Eriksson H, Wilhelmsen L, et al. The influence of body fat distribution on the incidence of diabetes mellitus: 13.5 years of follow-up of the participants in the study of men born in 1913. Diabetes (1985) 34(10):1055-8. doi:10.2337/diab.34.10.1055

97. Larsson B, Svärdsudd K, Welin L, Wilhelmsen L, Björntorp P, Tibblin G. Abdominal adipose tissue distribution, obesity, and risk of cardiovascular disease and death: 13 year follow up of participants in the study of men born in 1913. Br Med J (Clin Res Ed) (1984) 288(6428):1401-4. doi:10.1136/ bmj.288.6428.1401

98. Lapidus L, Bengtsson C, Larsson B, Pennert K, Rybo E, Sjöström L. Distribution of adipose tissue and risk of cardiovascular disease and death: a 12 year follow up of participants in the population study of women in Gothenburg, Sweden. Br Med J (Clin Res Ed) (1984) 289(6454):1257-61. doi:10.1136/bmj.289.6454.1257

99. Björntorp P. Visceral obesity: a "civilization syndrome". Obes Res (1993) 1(3):206-22. doi:10.1002/j.1550-8528.1993.tb00614.x

100. Brunzell JD, Hokanson JE. Dyslipidemia of central obesity and insulin resistance. Diabetes Care (1999) 22:C10.

101. Kissebah AH, Krakower GR. Regional adiposity and morbidity. Physiol Rev (1994) 74(4):761-812.

102. Zamboni M, Armellini F, Milani MP, De Marchi M, Todesco T, Robbi R, et al. Body fat distribution in pre-and post-menopausal women: metabolic and anthropometric variables and their inter-relationships. Int J Obes Relat Metab Disord (1992) 16(7):495-504.

103. Fujioka S, Matsuzawa Y, Tokunaga K, Tarui S. Contribution of intra-abdominal fat accumulation to the impairment of glucose and lipid metabolism in human obesity. Metabolism (1987) 36(1):54-9. doi:10.1016/0026-0495(87) 90063-1

104. Rebuffé-Scrive M, Anderson B, Olbe L, Björntorp P. Metabolism of adipose tissue in intraabdominal depots in severely obese men and women. Metabolism (1990) 39(10):1021-5. doi:10.1016/0026-0495(90)90160-E

105. Matsuzawa Y, Shimomura I, Nakamura T, Keno Y, Kotani K, Tokunaga K. Pathophysiology and pathogenesis of visceral fat obesity. Obesity (1995) 3(S2):187S-94S. doi:10.1002/j.1550-8528.1995.tb00462.x

106. Enzi G, Gasparo M, Biondetti PR, Fiore D, Semisa M, Zurlo F. Subcutaneous and visceral fat distribution according to sex, age, and overweight, evaluated by computed tomography. Am J Clin Nutr (1986) 44(6):739-46.

107. Björntorp P. "Portal" adipose tissue as a generator of risk factors for cardiovascular disease and diabetes. Arterioscler Thromb Vasc Biol (1990) 10(4):493-6. doi:10.1161/01.ATV.10.4.493

108. Li C, Ford ES, Zhao G, Balluz LS, Giles WH. Estimates of body composition with dual-energy X-ray absorptiometry in adults. Am J Clin Nutr (2009) 90(6):1457-65. doi:10.3945/ajcn.2009.28141

109. Ford ES, Mokdad AH, Giles WH. Trends in waist circumference among US adults. Obes Res (2003) 11(10):1223-31. doi:10.1038/oby.2003.168

110. Howel D. Trends in the prevalence of abdominal obesity and overweight in English adults (1993-2008). Obesity (2012) 20(8):1750-2. doi:10.1038/ oby.2011.127

111. Okosun IS, Chandra KD, Boev A, Boltri JM, Choi ST, Parish DC, et al. Abdominal adiposity in US adults: prevalence and trends, 1960-2000. Prev Med (2004) 39(1):197-206. doi:10.1016/j.ypmed.2004.01.023

112. Peeters A, Magliano DJ, Backholer K, Zimmet P, Shaw JE. Changes in the rates of weight and waist circumference gain in Australian adults over time: a longitudinal cohort study. BMJ Open (2014) 4(1):e003667. doi:10.1136/ bmjopen-2013-003667

113. Wardle J, Boniface D. Changes in the distributions of body mass index and waist circumference in English adults, 1993/1994 to 2002/2003. Int J Obes (2008) 32(3):527-32. doi:10.1038/sj.ijo.0803740

114. Lahti-Koski M, Harald K, Männistö S, Laatikainen T, Jousilahti P. Fifteenyear changes in body mass index and waist circumference in Finnish adults. Eur J Cardiovasc Prev Rehabil (2007) 14(3):398-404. doi:10.1097/ HJR.0b013e32800feflf

115. Visscher T, Seidell J. Time trends (1993-1997) and seasonal variation in body mass index and waist circumference in the Netherlands. Int J Obes (2004) 28(10):1309-16. doi:10.1038/sj.ijo.0802761

116. Flegal KM, Ogden CL, Yanovski JA, Freedman DS, Shepherd JA, Graubard BI, et al. High adiposity and high body mass index-for-age in US children and adolescents overall and by race-ethnic group. Am J Clin Nutr (2010) 91(4):1020-6. doi:10.3945/ajcn.2009.28589
117. Mokha JS, Srinivasan SR, Dasmahapatra P, Fernandez C, Chen W, Xu J, et al. Utility of waist-to-height ratio in assessing the status of central obesity and related cardiometabolic risk profile among normal weight and overweight/ obese children: the Bogalusa Heart Study. BMC Pediatr (2010) 10(1):73. doi:10.1186/1471-2431-10-73

118. Rodríguez-Rodríguez E, Palmeros-Exsome C, López-Sobaler AM, Ortega RM; Research Group: 920030. Preliminary data on the association between waist circumference and insulin resistance in children without a previous diagnosis. Eur J Pediatr (2011) 170(1):35-43. doi:10.1007/s00431-010-1260-1

119. Freedman DS, Serdula MK, Srinivasan SR, Berenson GS. Relation of circumferences and skinfold thicknesses to lipid and insulin concentrations in children and adolescents: the Bogalusa Heart Study. Am J Clin Nutr (1999) 69(2):308-17.

120. Garnett SP, Baur LA, Cowell CT. The prevalence of increased central adiposity in Australian school children 1985 to 2007. Obes Rev (2011) 12(11):887-96. doi:10.1111/j.1467-789X.2011.00899.x

121. Okosun IS, Boltri JM, Eriksen MP, Hepburn VA. Trends in abdominal obesity in young people: United States 1988-2002. Ethn Dis (2006) 16(2):338-44.

122. Wabitsch M, Moss A, Kromeyer-Hauschild K. Unexpected plateauing of childhood obesity rates in developed countries. BMC Med (2014) 12(1):17. doi:10.1186/1741-7015-12-17

123. Wang CY, Gortmaker SL, Taveras EM. Trends and racial/ethnic disparities in severe obesity among US children and adolescents, 1976-2006. Int J Pediatr Obes (2011) 6(1):12-20. doi:10.3109/17477161003587774

124. Ashwell M, Hsieh SD. Six reasons why the waist-to-height ratio is a rapid and effective global indicator for health risks of obesity and how its use could simplify the international public health message on obesity. Int J Food Sci Nutr (2005) 56(5):303-7. doi:10.1080/09637480500195066

125. Savva S, Tornaritis M, Savva M, Kourides Y, Panagi A, Silikiotou N, et al. Waist circumference and waist-to-height ratio are better predictors of cardiovascular disease risk factors in children than body mass index. Int $J$ Obes (2000) 24(11):1453. doi:10.1038/sj.ijo.0801401

126. Ford ES. Clinical Guidelines on the Identification, Evaluation, and Treatment of Overweight and Obesity in Adults: The Evidence Report. Bethesda, MD: National Heart, Lung, and Blood Institute (2014).

127. Ruderman NB, Schneider SH, Berchtold P. The "metabolically-obese," normal-weight individual. Am J Clin Nutr (1981) 34(8):1617-21.

128. Griffiths C, Gately P, Marchant PR, Cooke CB. Cross-sectional comparisons of BMI and waist circumference in British children: mixed public health messages. Obesity (2012) 20(6):1258-60. doi:10.1038/oby.2011.294

129. Bullard KM, Saydah SH, Imperatore G, Cowie CC, Gregg EW, Geiss LS, et al. Secular changes in US prediabetes prevalence defined by hemoglobin Alc and fasting plasma glucose. Diabetes Care (2013) 36(8):2286-93. doi:10.2337/ dc12-2563

130. Egan BM, Stevens-Fabry S. Prehypertension [mdash] prevalence, health risks, and management strategies. Nat Rev Cardiol (2015) 12(5):289-300. doi:10.1038/nrcardio.2015.17

131. CDC. Disability and Risk Factors: Obesity and Overweight. Centers for Disease Control and Prevention (2016). Available from: https://www.cdc. gov/nchs/fastats/obesity-overweight.htm

132. Cunningham SA, Kramer MR, Narayan KV. Incidence of childhood obesity in the United States. N Engl J Med (2014) 370(5):403-11. doi:10.1056/ NEJMoa1309753

Conflict of Interest Statement: The authors declare that the research was conducted in the absence of any commercial or financial relationships that could be construed as a potential conflict of interest. PM is an independent clinical consultant, writes articles and books that include the topics presented herein, and has a business website pertaining to health and fitness (www.philmaffetone.com). IR-D works for a health and fitness company. PL is an independent consultant, writes articles and books, and has a website pertaining to performance, health, and longevity (www. plewsandprof.com).

Copyright $\odot 2017$ Maffetone, Rivera-Dominguez and Laursen. This is an open-access article distributed under the terms of the Creative Commons Attribution License (CC BY). The use, distribution or reproduction in other forums is permitted, provided the original author(s) or licensor are credited and that the original publication in this journal is cited, in accordance with accepted academic practice. No use, distribution or reproduction is permitted which does not comply with these terms. 